\title{
Ferutinin content and cytotoxic effects of various Ferula L. species on prostate cancer (PC-3) cell line
}

\author{
Şüra BAYKAN 1 * (D), Fadime AYDOĞAN 1 (D), Mert Burak ÖZTÜRK 2 (D), Bilge DEBELEÇ-BÜTÜNER ${ }^{3}$ (D), \\ Çiğdem YENGIN 4 (D), Bintuğ ÖZTÜRK ${ }^{1}$ (D) \\ 1 Ege University, Faculty of Pharmacy, Department of Pharmaceutical Botany, 35040, Bornova, İzmir, Turkey. \\ 2 Ege University, Faculty of Engineering, Department of Bioengineering, 35040, Bornova, İzmir, Turkey. \\ 3 Ege University, Faculty of Pharmacy, Department of Biotechnology, 35040, Bornova, İzmir, Turkey. \\ 4 Ege University, Faculty of Pharmacy, Pharmaceutical Sciences Research Center, 35040, Bornova, İzmir, Turkey. \\ * Corresponding Author. E-mail: sura.baykan@ege.edu.tr (Ş.B.); Tel. +90 23238822 41-31 40; Fax. +902323885258.
}

Received: 28 May 2019 / Revised: 23 October 2019 / Accepted: 28 October 2019

\begin{abstract}
Ferula L. is represented by 23 taxa in Turkish flora. Most of the species are known as "Caksir" and roots are used as aphrodisiac in Anatolia. The aim of this study is to investigate the cytotoxic potential of roots of twelve different Ferula L. species distributing in Anatolia on prostate cancer cell line PC-3. Three extracts with different polarity were prepared from grounded roots of plants by ultrasonic solvent extraction. WST assay was performed to evaluate the cytotoxic effects of extracts. High cytotoxic activity was observed in F. elaeochytris, $F$. drudeana chloroform extracts and F. szowitsiana hexane extract (IC50: $3.21 \pm 0.24 \mu \mathrm{g} / \mathrm{ml}, 5.92 \pm 0.53 \mu \mathrm{g} / \mathrm{ml}, 8.03 \pm 0.51 \mu \mathrm{g} / \mathrm{ml}$ respectively) whereas methanol extracts of all species had no cytotoxic activity. F. tingitana chloroform extract induced high proliferation in dose dependent manner. A daucane ester "ferutinin" content was evaluated among the extracts by UPLC and it is found in highest concentrations in F. tenuissima and F. halophila hexane extracts ( $167380 \mu \mathrm{g} / \mathrm{g}$ and $157160 \mu \mathrm{g} / \mathrm{g}$ respectively). Although there is not a direct relationship between ferutinin content and cytotoxicity on PC-3, F. elaeochytris, F. drudeana, F. szowitsiana and F. tenuissima can be good candidates for the further studies for finding lead phytochemical compounds for prostate cancer treatment.
\end{abstract}

KEYWORDS: Ferula, ferutinin, cytotoxic, PC-3, prostate cancer.

\section{INTRODUCTION}

The genus Ferula L. (Apiaceae) comprises about 180-185 species distributed from Asia, North Africa to North America[1] . It is represented by 23 taxon in flora of Turkey, 13 of which are endemic (\% 62.3) and mainly distributed in Mediterranean, South-East and Inner Anatolia [2] .High endemism ratio indicates the position of this genus for Anatolia. The taxonomic and morphologic revision of Ferula $\mathrm{L}$ in Turkey is performed in 2005 [3]. Ferula species are erect, perennial plants growing up to $2-5 \mathrm{~m}$ tall. Roots are thick, woody, hard and fibrous. Basal cauline leaves are taxonomically important characters, 3-7 pinnate, segments differ filiform to setaceous. Inflorescence is paniculate-corymbose, petals are yellow $[4,5]$.

Most of the species are known as "çakşır otu, cağşır and at kasnısı" and used as aphrodisiac, tonic, antimicrobial, expectorant, in hemorrhoids and urinary diseases in Anatolian traditional medicine. Boiled leaves of F. communis L. F. orientalis L, F. rigidula DC. are consumed as food in east Anatolia. Roots of $F$. elaeochytris are used to increase the sexual performance in Adana, Hatay region[6]. Researches on cytotoxic and cancer preventing activities and hormonal effects of Ferula species have an increasing interest in recent years. Activities are generally related to the daucane sesquiterpenes and coumarin derivatives as the main metabolite groups of genus [7-13]. Especially ferutinin (a daucane type sesquiterpene ester) has been reported as a phytoestrogen acting as agonist for ER- $\alpha$ and agonist/antagonist for ER- $\beta$ [14].

Prostate cancer is a life-threatening disease for male as it is the third most common cause of death from cancer among men [15]. New approaches are needed for the treatment of PC-3 because of the side effects and complications of current treatment options like chemo-, hormonal or radiotherapy [16,17]. The literature indicates that many phytochemicals or extracts of medicinal plants have positive effects against commonly to occur cancers such as prostate as compared with these therapies [18-21]. PC-3 cells are androgen-independent

How to cite this article: Baykan Ş, Aydoğan F, Öztürk M.B, Debelec-Bütüner B, Yengin C, Öztürk B. Ferutinin content and cytotoxic effects of various Ferula L. species on prastate cancer (PC-3) cell line. J Res Pharm. 2020; 24(1): 142-149. 
epithelial cells derived from human prostate adenocarcinoma and a good system for basic anticancer investigations on prostate cancer [22]. The present study was designed to evaluate the ferutinin contents and cytotoxic effects of roots of Ferula species distributing in Anatolia on PC-3 cells.

\section{RESULTS}

\subsection{UPLC analysis}

Retention time was 10.58 and equation of the regression line formula and correlation coefficients were $\mathrm{Y}=-17497.7+119420$ and $\mathrm{R}^{2}=0.9999$ for ferutinin (Figure 2). The limit of detection (LOD) based on a signal-tonoise ratio (S/N: 3) was $0.153 \mu \mathrm{g} / \mathrm{ml}$. The limit of quantitation (LOQ) based on the signal to-noise ratio $(\mathrm{S} / \mathrm{N}$ : 10) using the lowest concentration in the calibration curve and the highest noise observed when injecting a blank was $510 \mu \mathrm{g} / \mathrm{g}$. The proposed method was applied to determine ferutinin content in chloroform and hexane extracts of 12 Ferula species. Among them ferutinin was detected in F. tenuissima, F. halophila, F. elaeochytris and F. duranii both chloroform and hexane extracts. The highest amount was determined in $F$. tenuissima and F. halophila hexane extracts $(167380 \mu \mathrm{g} / \mathrm{g}$ and $157160 \mu \mathrm{g} / \mathrm{g}$ respectively). A representative UPLC chromatograms were shown in Figure 1. The content of ferutinin in samples were listed in Table 1.

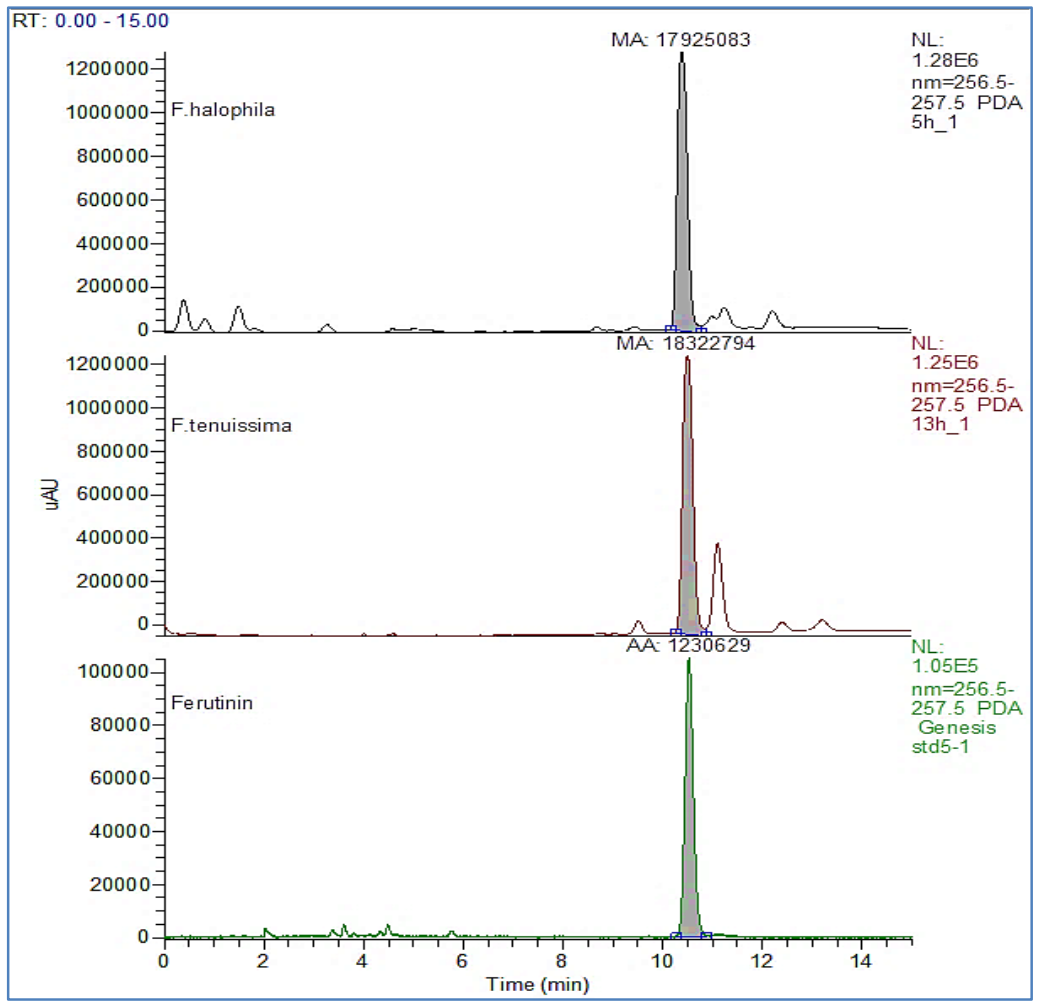

Figure 1. UPLC chromatograms of F. halophila, F. tenuissima hexane extracts and ferutinin.

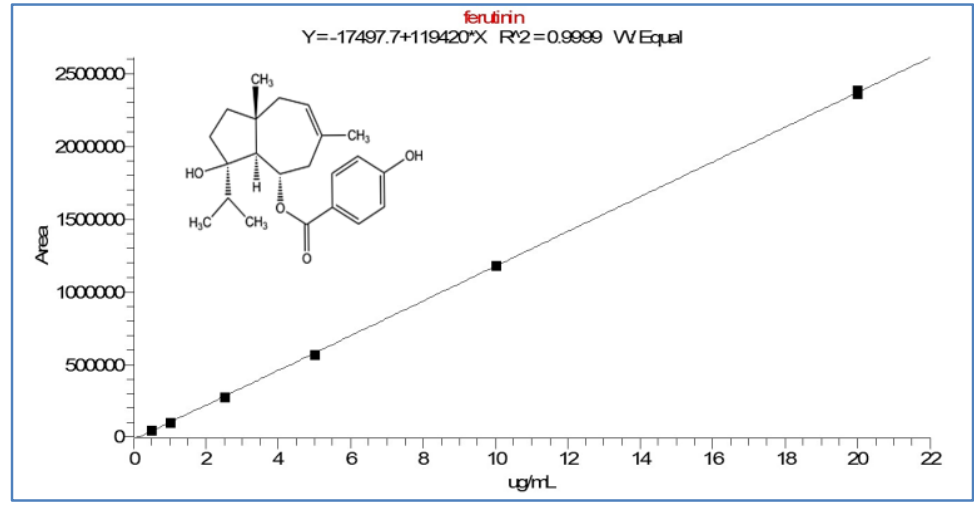

Figure 2. Ferutinin calibration curve (x: Concentration y: Area). 
Table 1. Ferutinin contents of Ferula L. species.

\begin{tabular}{lll}
\hline \multirow{2}{*}{ Species } & \multicolumn{2}{l}{ Amount (ug/g) } \\
\cline { 2 - 3 } & Chloroform & n-hexane \\
\hline F. communis subsp. communis & NF & $17739 \pm 0.027$ \\
F. drudeana & $\mathrm{NF}$ & $\mathrm{NF}$ \\
F. duranii & $14380 \pm 0.001$ & $32940 \pm 0.021$ \\
F. elaeochytris & $5380 \pm 0$ & $31590 \pm 0.006$ \\
F. halophila & $55820 \pm 0.02$ & $\mathbf{1 5 7 1 6 0 \pm 0 . 2 5 8}$ \\
F. huber-morathii & $\mathrm{NF}$ & 2241 \\
F. lycia & $\mathrm{NF}$ & $\mathrm{NF}$ \\
F. orientalis & $\mathrm{NF}$ & $19943 \pm 0.138$ \\
F. rigidula & $\mathrm{NF}$ & $1321 \pm 0.001$ \\
F. szowitsiana & $\mathrm{NF}$ & $779 \pm 0.003$ \\
F. tenuissima & $78660 \pm 0.003$ & $\mathbf{1 6 7 3 8 0 \pm 0 . 0 2 8}$ \\
F. tingitana & $\mathrm{NF}$ & $796 \pm 0.001$ \\
\hline
\end{tabular}

NF: Not found, SD: Mean \pm SD $(n=3)$

\subsection{Cytotoxic activity}

$\mathrm{IC}_{50}$ values of Ferula species tested via WST proliferation assay are given in Table 2. Some of the extracts were found to induce cell cytotoxicity with low $\mathrm{IC}_{50}$ values. Especially highest activities were observed for $F$. elaeochytris $(3.21 \pm 0.24 \mu \mathrm{g} / \mathrm{ml})$ and $F$. drudeana $(5.92 \pm 0.53 \mu \mathrm{g} / \mathrm{ml})$ chloroform extracts. F. szowitsiana hexane, chloroform extracts $(8.03 \pm 0.51 \mu \mathrm{g} / \mathrm{ml}$ and $11.14 \pm 2.85$ respectively) and $F$. tenuissima hexane extract $(11.64 \pm 1.15$ $\mu \mathrm{g} / \mathrm{ml}$ ) also produced significant inhibition on cells (Figure 3). Methanol fractions of all tested species showed no effect on cell viability. Besides F. tingitana chloroform extract showed dose dependent increase in cell proliferation.

Table 2. $\mathrm{IC}_{50}$ values of different extracts of Ferula L. species.

\begin{tabular}{llll}
\hline \multirow{2}{*}{ Species } & \multicolumn{2}{l}{$\mathrm{IC}_{50}(\mu \mathrm{g} / \mathrm{ml})$} & \\
\cline { 2 - 4 } & $\mathrm{n}-\mathrm{Hexane}$ & Chloroform & Methanol \\
\hline F. communis subsp. communis & $17.94 \pm 0.66$ & $40.55 \pm 3.89$ & NA \\
F. drudeana & $14.49 \pm 2.36$ & $5.92 \pm 0.53$ & NA \\
F. duranii & $61.46 \pm 3.23$ & $36.24 \pm 14.63$ & NA \\
F. elaeochytris & $25.55 \pm 2.87$ & $3.21 \pm 0.24$ & NA \\
F. halophila & $34.7 \pm 0.4$ & $38.14 \pm 2.53$ & NA \\
F. huber-morathii & $59.75 \pm 1.44$ & $39.82 \pm 1.74$ & NA \\
F. lycia & $35.54 \pm 1.12$ & $44.32 \pm 1.84$ & NA \\
F. orientalis & $24.78 \pm 0.88$ & $59.31 \pm 2.52$ & NA \\
F. rigidula & $60.72 \pm 2.02$ & $58.88 \pm 1.79$ & NA \\
F. szowitsiana & $8.03 \pm 0.51$ & $11.14 \pm 2.85$ & NA \\
F. tenuissima & $11.64 \pm 1.15$ & $17.64 \pm 1.37$ & NA \\
F. tingitana* & $23.9 \pm 0.52$ & NA & NA \\
\hline
\end{tabular}

Data are presented as means \pm standard deviation (SD).

NA: Not Active $\left(\mathrm{IC}_{50}>100\right.$ accepted as NA)

* Dose dependent proliferation was determined 


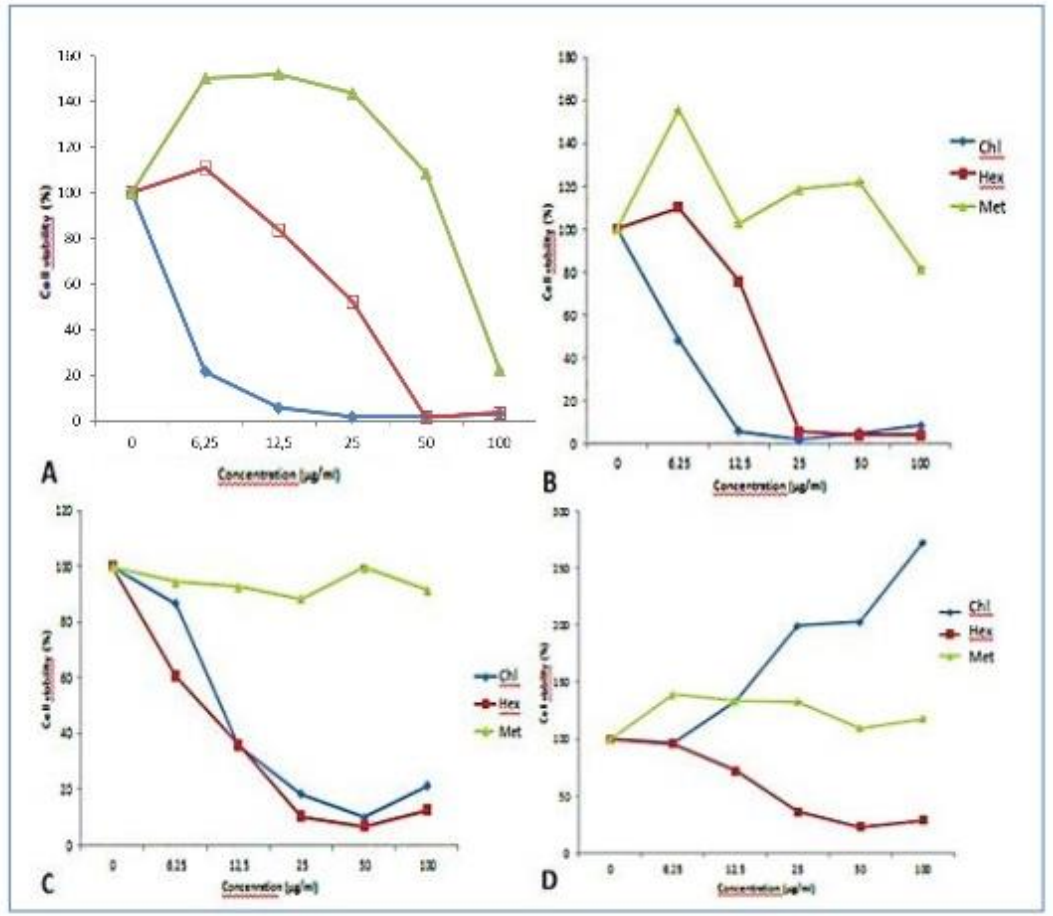

Figure 3. Dose response curves of selected Ferula extracts on PC-3 cells A. F. elaeochytris B. F. drudeana C. F. szowitsiana D. F. tingitana (x: concentration $(\mu \mathrm{g} / \mathrm{ml})$, y: cell viability $(\%)$.

\section{DISCUSSION}

Ferutinin is a daucane type sesquiterpene ester which was first described in 1973 by Saidkhodzhaev A from F. tenuisecta [24]. It has been reported from several Ferula species such as F. communis, F. elaeochytris, F. orientalis, F. tenuissima, F. halophila and F. rigidula to date [25-34]. Like phytochemical reports, in our study ferutinin was determined in all these Ferula species. Previous studies on F. szowitsiana and F. tingitana could not lead the isolation of this compound possibly due to the sparingly amount of ferutinin [28,35]. Moreover, to the best of our knowledge this is the first report of this compound found also in F. duranii and F. hubermorathii.

In our study 12 Ferula species were tested for cytotoxic activities and significant results were observed on especially chloroform and hexane extracts. None of the methanol extract had caused cell death on PC-3. Up to now Ferula species have been reported to have cytotoxic properties and most of the them were associated with especially nonpolar sesquiterpene contents. So, it can be said that also in our extracts nonpolar molecules are responsible for the cytotoxic activity. The significant result observed by F. elaeochytris chloroform extract is in agreement with the previous report of Alktahib et al who were tested sesquiterpene esters isolated from F. elaeochytris on leukemia cell lines (K562R (imatinib-resistant) human chronic myeloid leukemia and DA13b/M2BCR-ABL (dasatinib-resistant) mouse leukemia cell line) and found the compound elaeochytrin-A to be the most active compound on both cell lines ( $\mathrm{IC}_{50}=12.4$ and $7.8 \mu \mathrm{M}$, respectively) [9]. Ferutinin was tested in the same study and showed cytotoxic activity at $\mathrm{IC}_{50}: 25.3$ and $29.1 \mu \mathrm{M}$. The double bond between C8/C9 in the molecular structure marked to decrease the activity [9]. Similarly, it is difficult to depend the activity to ferutinin and to mention a parallel correlation between ferutinin amount and the cytotoxicity on PC-3 in our study. F. elaeochytris $(3.21 \pm 0.24 \mu \mathrm{g} / \mathrm{ml})$ and $F$. drudeana $(5.92 \pm 0.53 \mu \mathrm{g} / \mathrm{ml})$ chloroform extracts showed the highest activities but ferutinin content was not observed in same ratio. Nonetheless F. tenuissima and $F$. halophila hexane extracts including the highest amount of ferutinin $(167380 \mu \mathrm{g} / \mathrm{g}$ and $157160 \mu \mathrm{g} / \mathrm{g}$ respectively) among all extracts didn't provide the best inhibition on the proliferation. Additionally, in another paper published by our group ferutinin isolated from $F$. tenuissima was tested for its cytotoxic activity against PC-3 cell line and $\mathrm{IC}_{50}$ value was found as $19.7 \mu \mathrm{M}$ [23].All these results indicate that ferutinin is not the only responsible of the activity but the total extract including also the other daucane esters causes the effect by synergic activity. And, it seems possible to say that these are nonpolar derivatives since any methanol extract possesses cytotoxic activity. 
F. drudeana is an endemic species of Anatolia. Chloroform extract of the plant has a valuable effect on PC-3 proliferation. Dall' Acqua et al reported the antiproliferative effect of daucane sesquiterpenoids against a panel of human tumor cell lines and indicated the importance of structure-activity relationships [35]. Further detailed investigation of sesquiterpenes and sesquiterpene coumarins of $F$. drudeana and its cytotoxic effects is important to discover lead compounds for prostate cancer. F. tingitana chloroform extract interestingly caused a high proliferation on the cell line (Figure 3-D). Since the cell proliferation is an important part of tissue repair process, F. tingitana found to be a good candidate for wound healing investigations.

\section{CONCLUSION}

In conclusion, twelve Ferula species distributed in Anatolia were investigated for their cytotoxic effects on PC-3 cells and ferutinin contents were evaluated. F. elaeochytris and F. drudeana showed highest activities and there was not any correlation between ferutinin content and activity. Activity detected in the nonpolar fractions suggests the sesquiterpenes should be the responsible of the activities.

\section{MATERIALS AND METHODS}

\subsection{Plant Materials}

The roots of 12 Ferula species were collected from different origins of Anatolia in between 2013-2015 at the flowering stages. Plants were identified by the authors and voucher specimens have been deposited in the herbarium of Ege University (IZEF), Faculty of Pharmacy, Izmir, Turkey (www.izef.ege.edu.tr). Details of the collection localities and dates are presented in Table 3.

Table 3. Collection sites, voucher specimens of Ferula L. species.

\begin{tabular}{|c|c|c|}
\hline Plant name & Locality & Herbarium no (IZEF) \\
\hline F. communis subsp. communis & Izmir, Selcuk, Near Ephesus,50 m & 5519 \\
\hline F. drudeana* & Kayseri, Yahyalı, 1529 m & 5520 \\
\hline F. duranii $*$ & Antalya, Akseki, Çukurköy, 1500 m & 5521 \\
\hline F. elaeochytris & Kayseri, Yahyalı, 1200m & 5522 \\
\hline F. halophila* & Konya, Cihanbeyli, Tuzgölü, 900m & 5523 \\
\hline F. huber-morathii * & Muş-Varto road $40 . \mathrm{km}, 1280 \mathrm{~m}$ & 5524 \\
\hline F. lycia* & Antalya, Elmalı, 1030 m & 5525 \\
\hline F. orientalis & Muş-Varto road $40 . \mathrm{km}, 1280 \mathrm{~m}$ & 5527 \\
\hline F. rigidula & Malatya, Dogansehir, 1280 m & 5528 \\
\hline F. szowitsiana & Konya, Cihanbeyli, Tuzgölü, 900m & 5529 \\
\hline F. tenuissima* & Osmaniye, Yarpuz, 940 m & 6046 \\
\hline F. tingitana & Mugla, Yilanlı Mountain, $860 \mathrm{~m}$ & 5530 \\
\hline
\end{tabular}

*Endemic species in Turkey

\subsection{Extraction}

Dried and ground roots (10 g each) of the plants were extracted sequentially with n-hexane, chloroform and methanol at room temperature three times each, in an ultrasonic bath $(3 \times 300 \mathrm{ml}, 3 \mathrm{~h}$ for each). The combined extracts were evaporated separately under reduced pressure to dryness at 40 ${ }^{\circ} \mathrm{C}$ using Buchi Rotavapor. Dried extracts were stored at $4{ }^{\circ} \mathrm{C}$ until studied. Yields of the extracts are given in Table 4.

\subsection{UPLC analysis}

\subsubsection{Preparation of the standard and samples}

Standard ferutinin was isolated and purified in our laboratory from Ferula tenuissima and the kindly provided by Aydogan et al. [23]. A stock solution of standard was prepared in chloroform in a concentration of $1 \mathrm{mg} / \mathrm{ml}$. Serial dilutions of the stock solutions were made to obtain $0.5-20 \mu \mathrm{g} / \mathrm{ml}$. $10 \mu \mathrm{L}$ of triplicate was 
injected into each standard solution to see the reproducibility of the detector response at each concentration level. The peak areas obtained from the injections were plotted against the concentrations to establish the calibration graph. For each plant sample, a solution of $1 \mathrm{mg}$ of dry extract per $\mathrm{mL}$ of hexane and chloroform was prepared. All solvents were filtered through a $0.45 \mu \mathrm{m}$ filter prior to use and degassed in an ultrasonic bath.

Table 4. Extraction yields of Ferula L. species.

\begin{tabular}{lccc}
\hline \multirow{2}{*}{ Species } & \multicolumn{3}{c}{ Extraction Yield (\%) } \\
\cline { 2 - 4 } & n-hexane & Chloroform & Methanol \\
\hline F. communis subsp. communis & 3.04 & 0.87 & 4.18 \\
F. drudeana & 2.45 & 4.68 & 5.86 \\
F. duranii & 5.65 & 0.94 & 5.69 \\
F. elaeochytris & 3.96 & 1.54 & 1.22 \\
F. halophila & 14.77 & 3.9 & 8.69 \\
F. huber-morathii & 3.52 & 1.26 & 2.23 \\
F. lycia & 2.87 & 2.57 & 7.49 \\
F. orientalis & 5.3 & 0.78 & 6.06 \\
F. rigidula & 8.88 & 3.41 & 8.45 \\
F. szowitsiana & 1.53 & 0.75 & 5.28 \\
F. tenuissima & 0.91 & 1.96 & 0.66 \\
F. tingitana & 4.95 & 0.95 & 6.72 \\
\hline
\end{tabular}

\subsubsection{UPLC conditions}

The analysis was performed with a system consist of Thermo Scientific Accela (USA, San Jose)-UPLC equipped with solvent degasser, binary pump, auto sampler and PDA detector. Separations were carried out using HICHROM C-18 column $(250 \mathrm{~mm} \times 4.6 \mathrm{~mm}$ i.d., $5 \mu \mathrm{m})$. A flow rate of $1000 \mu \mathrm{l} / \mathrm{min}$ of isocratic water/acetonitrile $(30: 70 \mathrm{v} / \mathrm{v})$ was performed for $15 \mathrm{~min}$. per sample. The injection volume was $10 \mu \mathrm{l}$ and detection wavelength for PDA was $257 \mathrm{~nm}$. Quantitative evaluation of standards and samples was performed via peak area using the chromatography software XCalibur (Thermo Fisher Scientific). All analyses were triplicated. Linearity (between 5 equidistant points at the concentrations of 0.5 and $5.0 \mathrm{mg} / \mathrm{mL}-1$, observing the model-fitting through Analysis of Variance - ANOVA, 95\%. The limits of detection (LOD) were established at a signal to noise ratio $(\mathrm{S} / \mathrm{N})$ of 3 . The limits of quantification $(\mathrm{LOQ})$ were established at a signal to noise ratio $(\mathrm{S} / \mathrm{N})$ of 10 . LOD and LOQ were experimentally verified by the nine injections of reference compounds in LOQ concentrations.

\subsection{Cytotoxic activity}

\subsubsection{Cell Culture}

The PC-3 cells were obtained from American Type Culture Collection (ATCC Manassas, VA). PC-3 cells were propagated using DMEM F-12 supplemented with 5\% FBS, L-glutamine $(2 \mathrm{mM})$, penicillin $(100 \mathrm{U} / \mathrm{mL})$ and streptomycin $(100 \mu \mathrm{g} / \mathrm{mL})$ at $37^{\circ} \mathrm{C}$ with $5 \% \mathrm{CO}_{2}$.

\subsubsection{WST1 Proliferation Assay}

PC-3 $\left(8 \times 10^{3}\right)$ cells were seeded and grown in 96-well plates and incubated for 24 hours. Molecule treatments were performed for 48 hours and WST1 cell proliferation reagent (Roche Cat No: 05015944001) was used as recommended. Briefly, WST1 (1:10 final dilution) was added onto the cells at the end of treatments, and the cells were incubated for an additional 3 hours. At the end of the incubation, absorbance measurements at 450 and $690 \mathrm{~nm}$ reference wavelengths were performed to calculate the growth rate. Data are presented as means \pm standard deviation (SD). GraphPad prism 7.0 and The Student's $t$ test with two-tailed equal variance was applied to assess the statistical significance between pairs when necessary. $\mathrm{P}<0.05$ was accepted as significant.

Acknowledgements: This study was supported by Ege University Scientific Research Projects Committee (Project No. 13-ECZ-015).

Author contributions: Concept - S.B.; Design - S.B., B.Ö.; Supervision - S.B.; Resources - S.B., B.Ö.; Materials - B.D.B., M.B.Ö., S.B.; Data Collection and/or Processing - S.B., F.A., M.B.Ö., B.D.B., C.Y., B.Ö.; Analysis and/or Interpretation 
- S.B., F.A., M.B.Ö., B.D.B., C.Y., B.Ö.; Literature Search - S.B., F.A., M.B.Ö., B.D.B., C.Y., B.Ö.; Writing - S.B., F.A.,

M.B.Ö., B.D.B., C.Y., B.Ö.; Critical Reviews - S.B., F.A., M.B.Ö., B.D.B., C.Y., B.Ö.

Conflict of interest statement: The authors declared no conflict of interest.

\section{REFERENCES}

[1] Pimenov MG, Leonov MV. The Asian Umbelliferae biodiversity database (ASIUM) with particular reference to South-West Asian taxa. Turk J Botany. 2004; 28: 139-145.

[2] Güner A, Türkiye Bitkileri Listesi (Damarlı Bitkiler Kitabı), firsth ed.,ANG Vakfı, Nezahat Gökyiğit Botanik Bahçesi ve Flora Araştırmaları Derneği, Istanbul, Turkey, 2012.

[3] Sağıroğlu M. Phd Thesis. Türkiye Ferula L. (Umbelliferae) cinsinin revizyonu/Revision of Turkish Ferula L. (Umbelliferae). Faculty of Biology, Gazi University, Ankara, Turkey, 2005.

[4] Peşmen H. Ferula L. In: Davis PH. (Ed). Flora of Turkey and the East Aegean Islands, Vol IV. Edinburg University Pres, Edinburg, UK. 1972, pp. 440-453.

[5] Elibol Z, Menemen Y, Sağiroğlu M, Duman H. A molecular phylogenetic study on some Turkish Ferula L. (Apiaceae) species using nrDNA its sequences. Pakistan J Bot 2012; 44(2): 589-594.

[6] Baytop T, Türkiye' de Bitkilerle Tedavi Geçmişte ve Bugün, second ed., Nobel Tıp Kitabevleri, Istanbul, Turkey, 1999.

[7] Zanoli P, Zavatti M, Rivasi M, Baraldi, M. Ferula hermonis impairs sexual behavior in hormone-primed female rats. Physiol Behav. 2005; 86(1-2): 69-74. [CrossRef]

[8] Zanoli P, Rivasi M, Zavatti M, Brusiani F, Vezzalini F, Baraldi M. Activity of single components of Ferula hermonis on male rat sexual behavior. Int. J Impot Res. 2005; 17: 513-518. [CrossRef]

[9] Alkhatib R, Hennebelle T, Joha S, Idziorek T, Preudhomme C, Quesnel B, Sahpaz S, Bailleul F. Activity of elaeochytrin A from Ferula elaeochytris on leukemia cell lines. Phytochemistry. 2008; 69(17): 2979-2983. [CrossRef]

[10] Nazrullaev S, Saidkhodzhaev AI, Akhmedkhodzhaeva KS, Syrov VN, Rasulev BF, Khushbaktova ZA. Estrogen activity of terpenoids from plants of the genus Ferula. Chem Nat Compd. 2008; 44(5): 572-577. [CrossRef]

[11] Barthomeuf C, Lim S, Iranshahi M, Chollet P. Umbelliprenin from Ferula szowitsiana inhibits the growth of human M4Beu metastatic pigmented malignant melanoma cells through cell-cycle arrest in G1 and induction of caspasedependent apoptosis. Phytomedicine. 2008; 15(1-2): 103-111. [CrossRef]

[12] Iranshahi M, Barthomeuf C, Bayet-Robert M, Chollet P, Davoodi D, Piacente S, Rezaee R, Sahebkar A. Drimane-type Sesquiterpene Coumarins from Ferula gummosa Fruits Enhance Doxorubicin Uptake in Doxorubicin-resistant Human Breast Cancer Cell Line. J Tradit Complement Med. 2014; 4(2): 118-125. [CrossRef]

[13] Valiahdi SM, Iranshahi M, Sahebkar A. Cytotoxic activities of phytochemicals from Ferula species. DARU, J Pharm Sci. 2013; 21(1): 39-39. [CrossRef]

[14] Ikeda K, Arao, Otsuka H, Nomoto S, Horiguchi H, Kayama F, Ikeda K, Kato S, Kayama F, Kato S. Terpenoids found in the Umbelliferae family act as agonists/antagonists for ERa and ER $\beta$ : Differential transcription activity between ferutinine-liganded ERa and ER $\beta$. Biochem Biophys Res Commun. 2002; 291(2): 354-360. [CrossRef]

[15] Mitobe Y, Takayama K, Ichi Horie-Inoue K, Inoue S. Prostate cancer-associated IncRNAs. Cancer Lett. 2018; 418: 159166. [CrossRef]

[16] Deep G, Singh RP, Agarwal C, Kroll DJ, Agarwal R. Silymarin and silibinin cause G1 and G2-M cell cycle arrest via distinct circuitries in human prostate cancer PC3 cells: A comparison of flavanone silibinin with flavanolignan mixture silymarin. Oncogene. 2006; 25(7): 1053-1069. [CrossRef]

[17] American Cancer Society, Global Cancer Facts \& Figures, third ed., American Cancer Society Inc, Atlanta, GA, USA, 2015. [CrossRef]

[18] Reddy L, Odhav B, Bhoola KD. Natural products for cancer prevention: a global perspective. Pharmacol Ther. 2003; 99(1): 1-13. [CrossRef]

[19] Bemis DL, Katz AE, Buttyan R. Clinical trials of natural products as chemopreventive agents for prostate cancer. Expert Opin Investig Drugs. 2006; 15(10): 1191-1200. [CrossRef]

[20] Rahman MA, Sahabjada S, Akhtar J. Evaluation of anticancer activity of Cordia dichotoma leaves against a human prostate carcinoma cell line, PC3. J Tradit Complement Med. 2017; 7(3): 315-321. [CrossRef] 
[21] Kogiannou DAA, Kalogeropoulos N, Kefalas P, Polissiou MG, Kaliora AC. Herbal infusions; their phenolic profile, antioxidant and anti-inflammatory effects in HT29 and PC3 cells. Food Chem Toxicol. 2013; 61: 152-159. [CrossRef]

[22] Kaighn ME, Narayan KS, Ohnuki Y, Lechner JF, Jones LW. Establishment and characterization of a human prostatic carcinoma cell line (PC-3). Invest. Urol. 1979; 17(1): 16-23.

[23] Aydoğan F, Baykan Ş, Debeleç Bütüner B. Cytotoxic Activity of Daucane Sesquiterpene Esters Isolated from Endemic Ferula tenuissima HUB. MOR\& PEŞMEN. Turkish J. Pharm Sci. 2019; 16(4): In Press.

[24] Saidkhodzhaev AI, Nikonov GK. The structure of Ferutinin. Chem Nat Compd. 1973; 9(1): 25-26.

[25] Potapov VM, Nikonov GK. Esters of the roots of Ferula pallida. Chem Nat Compd. 1976; 12(6): 739-740. [CrossRef]

[26] Miski M, Jakupovic J. Daucane esters from Ferula rigidula. Phytochemistry. 1990; 29(1): 173-178. [CrossRef]

[27] Miski M, Mabry TJ, Saya Ö. New daucane and germacrane esters from Ferula orientalis var. orientalis. J Nat Prod. 1987; (50)5: 829-834. [CrossRef]

[28] Miski M, Mabry TJ. New daucane esters from Ferula tingitana. J Nat Prod 1986; 49(4): 657-660. [CrossRef]

[29] Miski, M, Ulubelen A, Mabry TJ. Six sesquiterpene alcohol esters from Ferula elaeochytris. Phytochemistry. 1983; 22(10): 2231-2233. [CrossRef]

[30] Golovina LA, Saidkhodzhaev AI, Malikov VM, Pimenov MG. Esters of Ferula soongarcia and Ferulia subtilis. Chem Nat Compd. 1987; 23(5): 639-639. [CrossRef]

[31] Khalilova ÉK, Saidkhodzhaev AI. Sesquiterpenoid esters of Ferula jaeschkeana. Chem. Nat. Compd. 1998; 34(4): 516516. [CrossRef]

[32] Galal AM, Abourashed EA, Ross SA, ElSohly MA, Al-Said MS, El-Feraly FS. Daucane sesquiterpenes from Ferula hermonis. J Nat Prod. 2001; 64(3): 399-400. [CrossRef]

[33] Sahpaz S, Neut C, Abedini A, Miski M. Antimicrobial Activity of the Sesquiterpene Esters of Ferula halophila Peşmen. Planta Med. 2013; 79: 19. [CrossRef]

[34] Abourashed EA, Galal AM, El-Feraly FS, Khan IA. Separation and quantification of the major daucane esters of Ferula hermonis by HPLC. Planta Med. 2001; 67(7): 681-682. [CrossRef]

[35] Iranshahi M, Arfa P, Ramezani M, Jaafari MR, Sadeghian H, Bassarello C, Piacente S, Pizza C. Sesquiterpene coumarins from Ferula szowitsiana and in vitro antileishmanial activity of 7-prenyloxycoumarins against promastigotes. Phytochemistry. 2007; 68(4): 554-561. [CrossRef]

[36] Dall'Acqua S, Linardi MA, Maggi F, Nicoletti M, Petitto V, Innocenti G, Basso G, Viola G. Natural daucane sesquiterpenes with antiproliferative and proapoptotic activity against human tumor cells. Bioorg Med Chem. 2011; 19(19): 5876-5885. [CrossRef]

This is an open access article which is publicly available on our journal's website under Institutional Repository at http://dspace.marmara.edu.tr. 